\title{
Analisis Wawasan Kebangsaan Melalui Buku Teks Kelas Rendah Sekolah Dasar Kurikulum Tematik 2013
}

\author{
Taufik Muhtarom ${ }^{1)}$ Danuri $^{2)}$ \\ ${ }^{1}$ PGSD FKIP Universitas PGRI Yogyakarta) \\ e-mail : (taufikmuhtarom@upy.ac.id) \\ ${ }^{2}$ PGSD FKIP Universitas PGRI Yogyakarta) \\ e-mail : danuri@upy.ac.id
}

\begin{abstract}
ABSTRAK
Penelitian ini bertujuan mendeskripsikan muatan nilai-nilai wawasan kebangsaan pada buku teks siswa kelas SD kelas rendah Kurikulum 2013 pada bagian wacana, petunjuk kerja, tagihan kerja, dan evaluasi. Data diperoleh dengan menggunakan teknik kajian isi. Metode yang digunakan dalam penelitian ini adalah kualitatif berupa study literature. Langkah yang dilakukan dalam penelitian adalah dengan menganalisis konten buku teks tematik siswa SD kelas rendah Kurikulum 2013. Adapun analisis datanya menggunakan analisis deskriptif-interpretatif melewati proses reduksi data, penyajian data dan penarikan kesimpulan. Hasil penelitian menunjukkan bahwa terdapat enam aspek dari nilai wawasan kebangsaan yang tercakup dalam buku teks tematik siswa kelas rendah sekolah dasar di antaranya adalah aspek Kesetiakawanan Sosial dengan rincian sebanyak 23\%, aspek Demokrasi dan Kedaulatan Rakyat sejumlah 11\%, Cinta Tanah Air dengan persentase 19\%, aspek Penghargaan terhadap Harkat dan Martabat Manusia sebagai Makhluk Ciptaan Tuhan Yang Maha Kuasa sebanyak 17\%, aspek Tekad Bersama untuk Berkehidupan Kebangsaan yang Bebas, Merdeka dan Bersatu sebanyak 17\%, aspek serta aspek Masyarakat Adil dan Makmur dengan persentase 14\%. Keenam aspek tersebut diajarkan melalui pembiasaan sikap dalam setiap aktivitas belajar baik sebelum, saat, maupun setelah pembelajaran di kelas, penanaman sikap melalui cerita dan muatan materi, pengenalan simbol dan maknanya, dan melalui pengenalan produk budaya dan keragaman bangsa, pemberian kebebasan dalam berpendapat.
\end{abstract}

Kata Kunci: Wawasan Kebangsaan, Buku Teks, Tematik

\begin{abstract}
This study aims to describe the values of national insight in the textbooks of elementary school students National Curriculum (Curriculum 2013) on the discourse, job information, training, and evaluation. Data were obtained by using content review technique. The method used in this research is qualitative study. The steps undertaken in the research is by analyzing the content of thematic textbooks of elementary students low grade Curriculum 2013. Data analysis using descriptive-interpretative process of data reduction, presentation of data and conclusions. The result of the research shows that there are six aspects of the national insight scores covered in thematic textbooks of low grade elementary school students in the aspect are Social True Solidarity aspect of 23\%, Democracy aspect and People's Sovereignty $11 \%$, Love the Homeland with percentage $19 \%$, aspects of the Awards for Praise and Dignity of Humans as Creatures of God Almighty as much as 17\%, Joint Detective aspect for Free National Life, Independent and United aspects as much as $17 \%$, and aspects of the Fair and Prosperous Community with a percentage of $14 \%$. The
\end{abstract}


six aspects of learning behaviors used in each learning activity before, during, and after classroom learning, plant attitudes through story and content, the introduction of symbols and their meaning, and through the introduction of products and the diversity of nations, giving freedom of expression.

Keywords: National Insights, Textbooks, Thematic

\section{PENDAHULUAN}

Pendidikan merupakan sebuah usaha sadar untuk membentuk peserta didik yang mandiri dan memiliki karakter yang kuat dalam menghadapi kehidupan di masa yang akan datang. Sebuah usaha tersebut tentunya perlu didorong dengan pemberian perlakuan, lingkungan, sarana dan metode pembelajaran yang baik. Pendidikan Indonesia terlepas dari segala permasalahannya membutuhkan sebuah sistem solusi yang berkesinambungan dalam upaya memperbaiki kualitas pendidikan agar tidak tertinggal dengan bangsa lain.

Salah satu permasalahan yang sedang dihadapi bangsa ini di era kemudahan arus informasi adalah tentang persatuan dan kesatuan elemen bangsa. Elemen tersebut penting dikarenakan bangsa Indonesia merupakan bangsa besar yang terdiri dari berbagai macam suku bangsa, agama, dan budaya. Berbagai perbedaan yang ada dalam bangsa Indonesia memang seolah menjadi khasanah dalam kekayaan budaya bangsa jika dapat dikelola dengan baik. Namun tidak demikian halnya jika berbagai perbedaan di dalam tubuh bangsa ini justru dimanfaatkan oleh sebagian orang untuk semakin memperuncing perbedaan yang ada. Isu-isu berkembangnya gerakan intoleransi, komunisme, radikalisme, separatisme perlu untuk segera ditindaklanjuti dengan serius.

Dewasa ini isu gerakan separatis, intoleran dan radikalisme semakin meningkat. Dalam laporan tahunannya, Ketua Komnas HAM Imdadun Rahmat menyampaikan adanya peningkatan kasus intoleransi atas kebebasan beragama dan berkeyakinan. Sepanjang 2016, berdasarkan pengaduan yang diterima Komnas HAM, tercatat ada 97 kasus. Data ini meningkat, karena pada 2014 tercatat ada 76 kasus dan 87 kasus pada 2015 (www.komnasham.go.id). Sementara itu berdasarkan survei Lembaga Kajian Islam dan Perdamaian (LaKIP) pada Oktober 2010 hingga Januari 2011, mengungkapkan hampir 50\% pelajar setuju tindakan radikal. Data itu menyebutkan $25 \%$ siswa dan $21 \%$ guru menyatakan Pancasila tidak relevan lagi. 
Sementara 84,8\% siswa dan 76,2\% guru setuju dengan penerapan Syariat Islam di Indonesia. Jumlah yang menyatakan setuju dengan kekerasan untuk solidaritas agama mencapai $52,3 \%$ siswa dan $14,2 \%$ membenarkan serangan bom (http://www.bbc.com).

Dunia pendidikan sebagai ujung tombak penanaman karakter bangsa perlu mendapatkan perhatian lebih untuk dapat mengatasi munculnya gerakan-gerakan atau pemikiran yang dapat merusak persatuan bangsa. Pemerintah saat ini telah mengembangkan buku teks tematik kurikulum nasional yang digunakan oleh sekolah-sekolah di Indonesia. Buku teks tematik kurikulum nasional tersebut diharapkan mampu untuk berperan dalam mengatasi permasalahan disintegrasi bangsa seperti yang disebutkan di atas. Hal ini jelas tak terbantahkan karena buku teks adalah buku yang sehari-hari dipakai dan dipelajari oleh siswa yang suatu saat nanti menjadi generasi penerus bangsa dan memegang tampuk estafet kemajuan bangsa Indonesia. Pentingnya buku teks sebagai sarana belajar tercermin dalam semboyan-semboyan seperti: buku adalah guru yang tak pernah jemu, buku adalah jendela informasi dunia, dan buku menjadi sarana pokok untuk menyimpan dan menyebarluaskan khazanah ilmu pengetahuan, teknologi informasi, dan seni. Bahkan UNESCO mencanangkan semboyan book for all, buku untuk semua (Aim Abdulkarim, 2007:71).

Namun sayangnya belum banyak diperoleh informasi/ studi mengenai muatan kebangsaan dalam buku teks tematik kurikulum nasional khususnya untuk anak SD. Berangkat dari hal tersebut maka kami mengajukan judul penelitian yaitu “Analisis Muatan Wawasan Kebangsaan dalam Buku Teks Siswa Kelas V Sekolah Dasar Kurikulum Nasional (Kurikulum Tematik 2013)”. Penelitian ini penting untuk dilakukan guna mendapatkan gambaran deskriptif mengenai seberapa banyak muatan wawasan kebangsaan pada buku teks tematik siswa sekolah dasar kurikulum nasional.

Pengertian buku teks pelajaran menurut Bacon dalam Tarigan dan Tarigan (2009: 12) adalah buku yang dirancang, dipersiapkan, dan disusun oleh para pakar dalam bidangnya serta dilengkapi dengan sarana pengajaran yang sesuai untuk digunakan di dalam kelas. A.J. Loveridge (1970: 9) menyatakan “A textbook is a 
school-book in which selected material on a certain sub-ject, in a written form which will satisfy a specific learning and teaching situation, is systematically set out for assimilation." Buku teks adalah buku sekolah yang memuat bahan yang telah diseleksi mengenai bidang studi tertentu, dalam bentuk tertulis yang memenuhi syarat tertentu dalam kegiatan belajar mengajar, disusun secara sistematis untuk diasimilasikan. Rumusan senada juga disampaikan oleh Muslich (2010: 50-51) buku ajar yang berupa buku teks adalah buku yang berisi uraian bahan tentang mata pelajaran atau bidang studi tertentu, yang disusun secara sistematis dan telah diseleksi berdasarkan tujuan tertentu, orientasi pembelajaran, dan perkembangan siswa, untuk diasimilasikan. Dari hasil kajian diketahui bahwa buku buku teks yang digunakan di sekolah sekolah di Indonesia terdiri atas empat jenis. Apabila ditinjau berdasarkan klasifi-kasi buku pendidikan, maka terdiri atas (1) buku teks pelajaran; (2) buku pengajaran; (3 buku pengayaan; dan (4) buku rujukan (Tim Pusat Perbukuan, 2006: 4).

Menurut Sitepu (2012: 21) berpendapat bahwa dilihat dari isi dan dan penyajiannya, buku teks pelajaran berfungsi sebagai pedoman manual bagi siswa dalam belajar dan bagi guru dalam membelajarkan untuk mata pelajaran tertentu. Buku ajar yang baik harus disusun secara lengkap dan sistematis, sesuai dengan kompetensi yang akan dicapai, disesuaikan dengan perkembangan siswa, serta memuat nilai-nilai karakter yang berpihak pada ideologi bangsa dan negara sesuai dengan kontrak standar isi kurikulum. Hal tersebut sesuai dengan pendapat Akbar (2013:34) yang menyatakan bahwa kriteria buku ajar yang baik antara lain: (1) Akurat (akurasi), yaitu dalam akurasi penulisannya perlu memperhatikan hal-hal mengenai kecermatan penyajian, tidak salah mengutip pendapat pakar; (2) relevansi, kesesuaian antara kompetensi yang harus dikuasai dengan cakupan isi, kedalaman pembahasan, dan kompeteni pembaca; (3) komunikatif artinya mudah dicerna pembaca; (4) lengkap dan sitematis; (5) berorientasi pada student centered; (6) berpihak pada ideologi bangsa dan negara. 7) menggunakan kaidah bahasa yang benar; (8) terbaca. Selain itu dalam logika penulisan suatu bahasa diikat oleh kaidah baik dan benar. 
Sementara itu penelitian mengenai analisis buku teks belum banyak dilakukan, kalaupun ada baru sebatas konten dan struktur penulisan yang belum mengarah ke analisis muatan wawasan kebangsaan. Seperti yang disebutkan oleh Anwar (2015:1) mengatakan bahwa hasil penelitian menunjukkan bahwa (1) sebagian besar indikator keterpaduan pada buku teks sesuai, tetapi masih ada kesalahan penomoran KD yang sesuai dengan Permendikbud Nomor 67 Tahun 2013 dan ketidaksesuaian materi dengan KD yang tercantum (2) muatan scientifi c approach yang tercantum pada buku teks mencakup kegiatan bervariasi yang mengarahkan siswa untuk berinteraksi dengan lingkungan dalam membangun pengetahuan (3) muatan authenthic assessment sudah memenuhi sebagian besar indikator, tetapi masih perlu dilengkapi dengan rubrik penilaian untuk membantu guru dalam menerapkan penilaian tersebut. Hal tersebut juga senada dengan yang diungkapkan oleh Hidayatul (2015: 235) yang mengatakan bahwa berdasarkan penelitiannya menganai analisis buku teks tematik kurikulum 2013 didapat kesimpulan bahwa (1) aspek kesesuian isi/ materi dengan kurikulum dan keterampilan partisipasi belum memenuhi standar kelayakan, sementara pengetahuan kewarganegaraan, keterampilan intelektual, dan karakter kewarganegaraan telah memenuhi standar kelayakan, (2) aspek pendekatan scientific belum memenuhi standar kelayakan, (3) aspek penilaian autentik telah memenuhi standar kelayakan, (4) aspek bahasa belum memenuhi standar kelayakan, (5) aspek grafika belum memenuhi standar kelayakan, dan (6) faktorfaktor penyebab munculnya permasalahan buku tersebut adalah penyusunan buku teks masih terjebak pada aspek kognitif, PPKn digunakan sebagai alat untuk melanggengkan kekuasaan, dan sulitnya menerapkan penilaian buku dengan mekanisme bertingkat.

Istilah Wawasan Kebangsaan terdiri dari dua suku kata yaitu "Wawasan" dan "Kebangsaan". Secara etimologi menurut Kamus Besar Bahasa Indonesia (1989) istilah wawasan berarti (1) hasil mewawas; tinjauan; pandangan dan dapat juga berarti (2) konsepsi cara pandang. Dalam kamus tersebut diberikan contoh "Wawasan Nusantara" yaitu wawasan (konsepsi cara pandang) dalam mencapai Tujuan Nasional yang mencakup perwujudan Kepulauan Nusantara sebagai satu 
kesatuan politik, sosial budaya, ekonomi dan pertahanan keamanan. Lebih lanjut diberikan pula contoh dalam pengertian lain seperti "Wawasan Sosial", sebagai "kemampuan untuk memahami cara-cara penyesuaian diri atau penempatan diri di lingkungan sosial (LAN, 2014:18). Sementara itu Parangtopo (1993) memberikan pengertian kebangsaan sebagai "tindak tanduk kesadaran dan sikap yang memandang dirinya sebagai suatu kelompok bangsa yang sama dengan keterikatan sosiokultural yang disepakati bersama. Berdasarkan wawasan kebangsaan itu, dinyatakan pula bahwa wawasan kebangsaan adalah suatu "wawasan yang mementingkan kesepakatan, kesejahteraan, kelemahan, dan keamanan bangsanya sebagai titik tolak dalam berfalsafah berencana dan bertindak".

Wawasan kebangsaaan sebagai sudut pandang suatu bangsa dalam memahami keberadaan jati diri dan lingkungannya pada dasarnya merupakan penjabaran dari falsafah bangsa itu sesuai dengan keadaan wilayah suatu negara dan sejarah yang dialaminya.Wawasan ini menentukan cara suatu bangsa memanfaatkan kondisi geografis, sejarah, sosial-budayanya dalam mencapai citacita dan menjamin kepentingan nasionalnya serta bagaimana bangsa itu memandang diri dan lingkungannya baik ke dalam maupun ke luar (LAN, 2014: 3). Dalam rangka menerapkan konsep wawasan kebangsaan, pada Seminar Pendidikan Wawasan Kebangsaan (1993) dikemukakan perlunya dipahami 2 (dua) aspek sebagai berikut: a) Aspek Moral Konsep wawasan kebangsaan mensyaratkan adanyaperjanjian diri atau commitment pada seseorang atau masyarakat untuk turut bekerja bagi kelanjutan eksistensi bangsa dan bagi peningkatankualitas kehidupan bangsa; b) Aspek Intelektual Konsep wawasan kebangsaan menghendaki pengetahuan yang memadai mengenai - yang dihadapi bangsa baik saat ini maupun di masa mendatang serta berbagai potensi yang dimiliki bangsa.

Berbicara mengenai wawasan kebangsaan, perlu menilik tentang konsep wawasan nusantara yang teah sejak dulu dirumuskan dalam perangkat konstitusi negara seperti yang tertuang dalam Kepres MPR No. IV/MPR/1973, tentang Garis Besar Haluan Negara Bab II Sub E, Pokok-pokok Wawasan Nusantara dinyatakan sebagai Wawasan dalam mencapai tujuan Pembangunan Nasional adalah Wawasan Nusantara mencakup: 1)Perwujudan Kepulauan Nusantara sebagai satu Kesatuan 
Politik dalam arti: a. Bahwa kebutuhan wilayah nasional dengan segala isi dan kekayaannya merupakan satu kesatuan wilayah, wadah, ruang hidup dan kesatuan matra seluruh bangsa, serta menjadi modal dan menjadi modal dan milik bersama bangsa. b. Bahwa Bangsa Indonesia yang terdiri dari berbagai suku dan berbicara dalam berbagai bahasa daerah, memeluk dan meyakini berbagai agama dan kepercayaan terhadap Tuhan Yang Maha Esa harus merupakan satu kesatuan bangsa yang bulat dalam arti seluas-luasnya. c. Bahwa secara psikologis, bahwa bangsa Indonesia harus merasa satu, senasib sepenanggungan, sebangsa dan setanah air, serta mempunyai satu tekad di dalam mencapai cita-cita bangsa. d. Bahwa Pancasila adalah adalah satu-satunya falsafah serta ideologi bangsa dan Negara, yang melandasi, membimbing dan mengarahkan bangsa menuju tujuannya. e. Bahwa seluruh Kepulauan Nusantara merupakan satu kesatuan hukum dalam arti bahwa hanya ada satu hokum yang mengabdi kepada kepentingan nasional.

Perwujudan Kepulaun Nusantara sebagai Kesatuanj Sosial dan Budaya dalam arti: a. Bahwa masyarakat Indonesia adalah satu, perikehidupan bangsa harus merupakan kaehidupan yang serasi dengan terdapatnya tingkat kemajuan masyarakat yang sama, merata dan seimbang serta adanya keselarasan kehidupan yang sesuai dengan kemajuan bangsa. b. Bahwa budaya Indonesia pada hakekatnya adalah satu, sedangkan corak ragam budaya yang ada menggambarkan kekayaan budaya yang menjadi modal dan landasan pengembangan budaya bangsa seluruhnya, yang hasil-hasilnya dapat dinikmati oleh seluruh bangsa Indonesia.

Sedangkan perwujudan Kepulauan Nusantara sebagai satu kesatuan Ekonomi dalam arti: a. Bahwa kekayaan wilayah Nusantara baik potensial maupun efektif adalah modal dan milik bersama bangsa, dan bahwa keperluan hidup seharihari harus tersedia merata di seluruh wilayah tanah air. b.Tingkat perkembangan ekonomi harus serasi dan seimbang di seluruh daerah, tanpa meninggalkan cirri khas yang dimiliki oleh daerah-daerah dalam mengembangkan ekonominya.

Perwujudan Kepulauan Nusantara sebagai satu Kesatuan Pertahanan dan Keamanan dalam arti: a. Bahwa ancaman terhadap satu daerah pada hakekatnya merupakan ancaman bagi seluruh bangsa dan negara. b. Bahwa tiap-tiap warga 
negara mempunyai hak dan kewajiban yang sama di dalam pembelaan Negara (Lemhanas, 1989: 7).

Ada beberapa dimensi dalam memaknai wawasan kebangsaan. Menurut LAN (2014: 23) menyatakan bahwa nilai Wawasan Kebangsaan yang terwujud dalam persatuan dan kesatuan bangsa memiliki 6 enam) dimensi manusia yang bersifat mendasar dan fundamental, yaitu: 1) Penghargaan terhadap harkat dan martabat manusia sebagai mahluk ciptaan Tuhan Yang Maha Kuasa; 2) Tekad bersama untuk berkehidupan kebangsaan yang bebas, merdeka, dan bersatu; 3) Cinta akan Tanah Air dan Bangsa; 4) Demokrasi atau Kedaulatan Rakyat; 5) Kesetiakawanan Sosial; 6) Masyarakat adil dan makmur. Wawasan Kebangsaan Indonesia mengamanatkan kepada seluruh bangsa agar menempatkan persatuan, kesatuan, serta kepentingan dan keselamatan bangsa dan negara di atas kepentingan pribadi atau golongan. Diharapkan manusia Indonesia sanggup dan rela berkorban untuk kepentingan bangsa. Sehubungan dengan itu hendaknya dipupuk penghargaan terhadap martabat manusia, cinta kepada Tanah Air dan Bangsa, demokrasi dan kesetiakawanan sosial. Mencermati makna Wawasan Kebangsaan tersebut, dapatlah dikemukakan bahwa Wawasan Kebangsaan Indonesia pada hakekatnya dilandasi oleh Pancasila sebagai falsafah dan pandangan hidup bangsa kita. Dengan Wawasan Kebangsaan yang dilandasi oleh pandangan hidup Pancasila, bangsa Indonesia telah berhasil merintis jalan menyelenggarakan misinya di tengah-tengah tata kehidupan di dunia. Untuk dapat memahami hakekat Wawasan Kebangsaan Indonesia perlu kiranya dipahami jati diri bangsa kita dan untuk itu perlu pula dipahami pandangan dan falsafah hidup yang dianut oleh bangsa Indonesia. Pendidikan tentang cinta negara dan bangsa perlu ditekankan di sekolah, hal ini senada dengan hasil penelitian dari Dasim Budimansyah (2010: 1) yang memperlihatkan bahwa globalisasi menantang kekuatan penerapan unsur jati diri dan memporakporandakan nilai-nilai adiluhung bangsa melalui agennya televisi. Untuk menanggulangi persoalan demikian program pendidikan kewarganegaraan harus diselenggarakan dengan mengacu pada konsep Citizenship Education. 


\section{METODE PENELITIAN}

Studi ini dikategorikan sebagai penelitian kualitatif. Dikatakan kualitatif karena studi ini lebih menekankan model penyampaian muatan wawasan kebangsaan dalam buku pelajaran. Karena merupakan studi pustaka, penelitian ini akan dilaksanakan di kampus Universitas PGRI Yogyakarta yang akan berlangsung dari Februari-April 2017.

Subjek penelitian ini adalah buku teks pelajaran tematik kurikulum nasional sekolah dasar. Pemilihan buku tersebut berdasarkan tingkat keterpakaian buku di sekolah dasar di wilayah Yogyakarta. Adapun objek penelitian ini adalah muatan kebangsaan yang termuat dalam buku teks tematik kelas rendah sekolah dasar kurikulum nasional (kurikulum 2013). Teknik analisis data yang digunakan dalam penelitian ini adalah analisis isi (content analysis).

\section{HASIL DAN PEMBAHASAN}

\section{a. Hasil Penelitian}

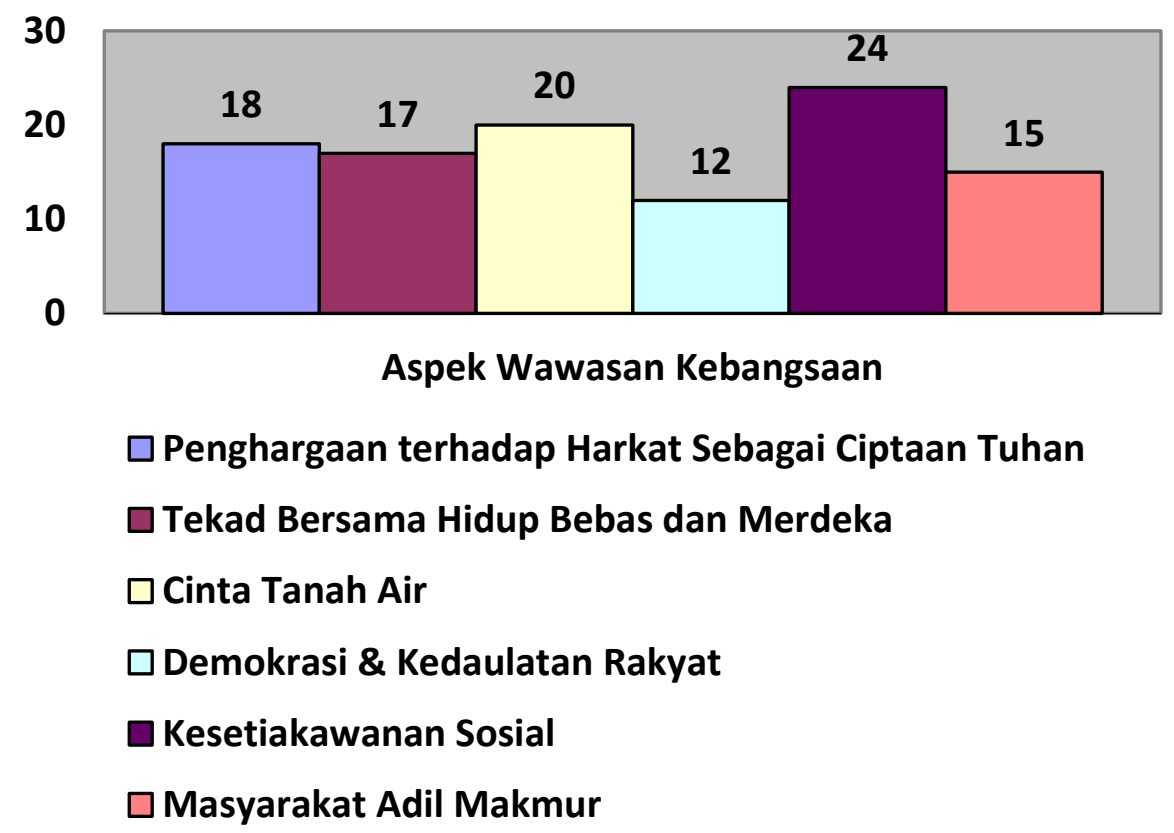

Gambar 1. Grafik Hasil Wawasan Kebangsaan melalui Kurikulum 2013

Jika ditilik dari grafik di atas dapat diketahui bahwa muatan aspek Kesetiakawanan Sosial yang paling banyak termuat dalam buku K13 kelas rendah dengan jumlah persenannya adalah $23 \%$, sementara itu yang paling sedikit adalah 
aspek Demokrasi dan Kedaulatan Rakyat dengan jumlah persenan hanya $11 \%$. Sedangkan terbanyak kedua adalah aspek Cinta Tanah Air dengan persentase 19\%, disusul aspek Penghargaan terhadap Harkat dan Martabat Manusia sebagai Makhluk Ciptaan Tuhan Yang Maha Kuasa dengan persentase 17\% kemudian aspek Tekad Bersama untuk Berkehidupan Kebangsaan yang Bebas, Merdeka dan Bersatu serta aspek Masyarakat Adil dan Makmur dengan persentase masingmasingnya adalah $17 \%$ dan $14 \%$.

\section{b. Pembahasan}

1) Penghargaan terhadap Harkat dan Martabat Manusia sebagai Makhluk Ciptaan Tuhan Yang Maha Kuasa

Aspek ini dikaji berdasarkan muatan pelajaran yang berkaitan dengan penanaman kehidupan yang religius yang diharapkan supaya siswa dapat menyadari akan kodrat harkat dan martabat dirinya sebagai makhluk ciptaan Tuhan Yang Maha Kuasa. Diperoleh data bahwa untuk aspek ini ditemukan sejumlah $17 \%$ data lembaran halaman dari buku teks tematik K13 revisi 2017 pada kelas 1 dan kelas 2 SD. Mencermati hasil kajian aspek pertama dengan bukti seperti yang dipaparkan di atas, dapat ditarik kesimpulan bahwa penanaman aspek pertama tentang Penghargaan Harkat dan Martabat Manusia sebagai Makhluk Ciptaan Tuhan diajarkan dan diberikan melalui pembiasaan berdoa sebelum melakukan aktivitas, saling menghargai dan menghormati antar pemeluk agama lain, ajakan mensyukuri nikmat dari Tuhan dan penyadaran akan anggota tubuh dan makhluk ciptaan Tuhan yang lain. Hal ini sejalan dengan yang pernah diteliti oleh M. Anwar Rubei (2018:1) yang menyatakan bahwa hasil penelitian menunjukkan bahwa guru PPKn telah melakukan penanaman sila Ketuhanan Yang Maha Esa, yaitu: (1) pengenalan nilai-nilai sila pertama, (2) memberikan penguatan positif (3) keteladanan guru, (4) pembiasaan sikap, (5) pembudayaan nilai sila pertama.

Pada hasil penelitian di atas disebutkan bahwa strategi pertama dalam mengenalkan ketuhanan yang Maha Kuasa kepada siswa adalah 
dengan pengenalan simbol sila pertama kepada para siswa, sama halnya dengan temuan hasil dalam penelitian ini. Dalam buku tematik K13 kelas rendah ditemukan bahwa cara penanaman aspek Penghargaan terhadap Harkat dan Martabat sebagai Makhluk Ciptaan Tuhan Yang Maha Esa salah satunya adalah dengan cara pengenalan simbol Pancasila dan pemaknaan serta pembiasaan melalui rancangan kegiatan yang dapat menumbuhkan aspek tersebut.

2) Tekad Bersama untuk Berkehidupan Kebangsaan yang Bebas, Merdeka, dan Bersatu

Pada aspek ini titik berat pengajarannya adalah pada bagaimana siswa dibiasakan untuk bisa berkehidupan dengan tekad bersama agar dapat hidup berkebangsaan yang bebas, merdeka dan bersatu meskipun berbedabeda asal muasal, agama, ras, suku, pendapat dan lain sebagainya. Diperoleh data bahwa untuk aspek ini ditemukan sejumlah 16\% data lembaran halaman dari buku teks tematik K13 revisi 2017 pada kelas 1 dan kelas 2 SD. Mencermati hasil kajian aspek pertama dengan bukti seperti yang dipaparkan di atas, dapat ditarik kesimpulan bahwa penanaman aspek kedua tentang Tekad Bersama untuk Hidup Bebas, Merdeka dan Bersatu diajarkan dan diberikan melalui pembiasaan mentaati aturan yang ada, kumpulan aktivitas yang membebaskan siswa untuk berekspresi sesuai dengan kemampuannya, pembiasaan saling menghargai dalam perbedaan untuk mencapai persatuan, pembiasaan kebersamaan dalam melakukan suatu aktivitas untuk merekatkan persatuan.

3) Cinta akan Tanah Air dan Bangsa

Aspek ketiga yaitu cinta tanah air dan bangsa menjadi satu bagian penting yang tidak bisa dilewatkan dalam pengajaran/ pendidikan di Indonesia. Melihat dari data di atas dapat kita kemukakan bahwa pengajaran aspek Cinta Tanah Air dan Bangsa disampaikan melalui pengajaran simbolsimbol negara seperti Pancasila dan bendera Indonesia, pengenalan produk budaya baik yang berupa kebiasaan maupun peralatan dan tempat tempat 
budaya bangsa Indonesia. Di dalam aspek ini diperoleh hasil kajian sebanyak 19\% muatan dalam buku teks tematik K13 termuat aspek ini.

Aspek ini menekankan pada pengajaran agar siswa dapat mencintai tanah air dan bangsanya melalui berbagai kegiatan pembiasaan maupun muatan materi yang dapat meningkatkan gairan cinta tanah air pada diri siswa sebagai bagian dari rakyat Indonesia. Aspek ini sangat penting ditekankan sejak dini agar generasi yang mendatang menjadi generasi penerus yang akan senantiasa dapat menjaga keutuhan NKRI dengan diawali dari kecintaan terhadap tanah air dan bangsanya sendiri. Jika latar belakang kemajemukan dan perbedaan budaya, agama, suku, ras, pandangan politik, tingkat ekonomi bangsa Indonesia yang sangat beragam tidak diimbangi dengan rasa cinta kepada tanah air Indonesia, maka tidak menutup kemungkinan akan sangat beresiko untuk terjadi konflik-konflik baik kecil maupun besar. Kemungkinan terburuk dari terus-menerus dan tidak berakhirnya konflik adalah disintegrasi bangsa, atau bahkan apa yang dikatakan sebagai failed state (Donald Emmerson, 2000: 95). Tentu kita tidak menginginkan ini terjadi maka sedini mungkin konsep cinta tanah air harus ditanamkan dan ini menjadi harga mati bagi keberlangsungan bangsa Indonesia ke depan.

4) Demokrasi atau Kedaulatan Rakyat

Seperti apa yang pernah disampaikan oleh Chamim dkk (2006:39) menjelaskan bahwa nilai demokrasi yaitu ditandai dengan adanya kebebasan (berpendapat, berkelompok, berpartisipasi), menghormati orang/kelompok lain, kesetaraan, kerjasama, persaingan, dan kepercayaan.

Dapat dilihat dari hasil kajian pada penelitian ini bahwa pengajaran nilai aspek keempat dari Wawasan Kebangsaan yang berupa nilai Demokrasi dan Kedaulatan Rakyat dalam buku tematik K13 kelas rendah adalah dilakukan melalui pengajaran materi tentang konsep demokrasi, pembiasaan musyawarah dalam pengambilan keputusan, pembiasaan penyampaian pendapat dengan sopan dan saling menghargai, pembiasaan penentuan keputusan dengan musyawarah, dan pembiasaan pemberian 
kebebasan dalam menentukan keputusan dengan dilandasi tanggungjawab dan saling menghormati.

Aspek keempat dalam Wawasan Kebangsaan ini ditanamkan kepada siswa lebih kepada pembiasaan dalam hal pengambilan keputusan bersama. Aspek ini menekankan pada ajaran demokrasi yaitu pengambilan segala keputusan dengan dilandasi oleh permusyawaratan dan memperhatikan aspirasi dari berbagai elemen dalam masyarakat dari rakyat oleh rakyat dan untuk rakyat. Aspek ini juga penting untuk diajarkan sejak dini karena merupakan landasan dalam berkehidupan kebangsaan terutama karena bangsa Indonesia terdiri dari berbagai macam perbedaan seperti suku, ras, agama dan kebudayaan. Serta penanaman kedaulatan rakyat bahwa komitmen bangsa Indonesia sebagai bangsa yang besar adalah rakyat mutlak yang menjadi penentu kebijakan arah pembangunan bangsa, bukan berdasar oligarki, monarki maupun milik golongan tertentu.

Pada penelitian ini diperoleh hasil kajian bahwa hanya sebanyak $11 \%$ dari literature buku siswa tematik K13 yang menanamkan aspek ini. Ini menarik untuk dikaji lebih lanjut mengingat pentingnya konsep demokrasi ditanamkan kepada para siswa sejak dini mengingat banyaknya perbedaan yang ada dalam diri bangsa Indoesia. Akan lebih baik jika konsep demokrasi ini mendapat porsi yang lebih banyak untuk dibiasakan dan diajarkan kepada siswa sekolah dasar untuk membentuk kepribadian bangsa Indonesia ke depan yang penuh dengan tantangan disitegrasi bangsa.

5) Kesetiakawanan Sosial

Aspek kelima dalam kajian/ penelitian ini adalah aspek nilai Kesetiawakawanan Sosial. Ini tidak kalah pentingnya untuk diajarkan sejak dini pula mengingat bangsa Indonesia merupakan bangsa yang beragam baik dari segi kebudayaan maupun tingkat kesejahteraan perekonomian. Penanaman nilai kesetiakawanan sosial sejak dini dapat menumbuhkan dan membuahkan sikap kepedulian sosial pada diri siswa kelak ketika mereka sudah dewasa nanti. Kodrat manusia sebagai makhluk sosial mengharuskan 
mereka untuk bisa hidup saling berdampingan dengan dilandasi saling peduli.

Berdasarkan data statistik sederhana, diperoleh data bahwa terdapat sebanyak 23\% dari keseluruhan muatan dalam buku teks tematik K13 yang mengusung tema/ aspek kesetiakawanan sosial. Ini menarik karena aspek ini menjadi aspek dengan jumlah porsi terbesar dari analisis yang telah dilakukan.

Dapat dilihat dari hasil analisis di atas bahwa pengajaran aspek kelima yaitu Kesetiakawanan Sosial diajarkan dalam buku teks tematik kelas rendah K13 melalui beberapa kegiatan pembiasaan untuk saling bekerjasama, saling membantu, materi bacaan tentang hidup saling tolong menolong, peduli dan mau membantu orang lain yang sedang kesusahan/ bencana, kebersamaan dan gotongroyong dalam menjaga lingkungan, berkawan dengan siapa saja tanpa membeda-bedakan, pembiasaan kerjasama dalam permainan dan olahraga, dan pembiasaan sikap saling memaafkan.

6) Masyarakat Adil dan Makmur

Aspek terakhir dari bidang kajian muatan Wawasan Kebangsaan adalah mengenai penanaman konsep pembentukan masyarakat yang adil dan makmur. Siswa sekolah dasar ke depan adalah menjadi bagian dari generasi yang akan bertumbuh menjadi masyarakat Indonesia yang mana menjadi harapan tumpuan generasi saat ini untuk ikut serta dalam pembentukan masyarakat Indonesia yang adil dan makmur. Diperoleh data hasil kajian bahwa terdapat sebanyak 14\% muatan aspek Masyarakat Adil dan Makmur dalam buku teks tematik K13 kelas rendah.

Dari kajian literatur di atas dapat ditarik kesimpulan bahwa pengajaran nilai aspek ke enam tentang masyarakat adil dan makmur dalam buku teks tematik K13 kelas rendah diajarkan melalui peragaan cerita fabel tentang konsep keadilan dan kemakmuran, pemberian contoh kebiasaan berbuat adil yang dapat diterapkan dalam kehidupan sehari-hari anak, pembiasaan berbuat adil meskipun dalam hal permainan sekalipun, 
pemberian materi konsep keadilan dan kemakmuran melalui lambang negara, pemberian materi keadilan dalam berbagi kepada sesama, pembiasaan keadilan dalam pembagian tugas sesuai perannya masingmasing, dan penjelasan dampak-dampak buruk jika tidak bisa berbuat adil. Hal ini sejalan dengan apa yang pernah disampaikan oleh Rusman (2010:251-252) bahwa kecenderungan peserta didik di SD/MI ketika belajar memunyai tiga karakteristik yang menonjol yaitu: konkret, integratif, dan hierakhis. Konkret berarti para siswa lebih senang dan paham jika diajarkan sesuatu konsep dengan cara langsung/ praktik, integratif berarti meluas meliputi beberapa aspek pengetahuan yang didapat dan hirarkis berarti bertahap dari mudah ke sukar dan dari sederhana ke komplek.

\section{SIMPULAN}

Terdapat enam aspek dari nilai wawasan kebangsaan yang tercakup dalam buku teks tematik siswa kelas rendah sekolah dasar di antaranya adalah dengan masing-masing ketersebarannya adalah sebagai berikut: aspek Kesetiakawanan Sosial sebanyak 23\%, aspek Demokrasi dan Kedaulatan Rakyat sejumlah 11\%, Cinta Tanah Air dengan persentase 19\%, aspek Penghargaan terhadap Harkat dan Martabat Manusia sebagai Makhluk Ciptaan Tuhan Yang Maha Kuasa sebanyak 17\%, aspek Tekad Bersama untuk Berkehidupan Kebangsaan yang Bebas sebanyak 17\%, aspek Merdeka dan Bersatu serta aspek Masyarakat Adil dan Makmur dengan persentase 14\%. Jika dilihat dari bentuk atau pola pengajaran muatan wawasan kebangsaan diperoleh kecenderungan adalah melalui pembiasaan sikap dalam setiap aktivitas belajar baik sebelum, saat, maupun setelah pembelajaran di kelas, penanaman sikap melalui cerita dan muatan materi, pengenalan simbol dan maknanya, dan melalui pengenalan produk budaya dan keragaman bangsa, pemberian kebebasan dalam berpendapat. 


\section{DAFTAR PUSTAKA}

Aim Abdulkarim. 2007. Analisis Isi Buku Teks dan Implikasinya dalam Memberdayakan Keterampilan Berpikir Siswa SMA. Forum Kependidikan. Vol. 26, No. 2, Maret 2007.

Akbar, Sa'dun. 2013. Instrumen Peningkatan Pembelajaran. Bandung. PT. Remaja Rosdakarya.

Anwar Novianto. 2015. Analisis Muatan Buku Teks Tematik Integratif, Scienttific Approach, dan Authentic Assesment Sekolah Dasar. Jurnal Kependidikan Volume 45, Nomor 1, Mei 2015, Halaman 1-15.

Chamim, dkk. 2006. Pendidikan Kewarganegaraan. Yogyakarta: Lembaga Penelitian dan Pengembangan Pendidikan (LP3) Universitas Muhammadiyah Yogyakarta.

Dasim Budimansyah. 2010. Tantangan Globalisasi terhadap Pembinaan Wawasan Kebangsaan dan Cinta Tanah Air di Sekolah. Jurnal Penelitian Pendidikan, Vol. 11, Nomor 1, April 2010.

Donald, Emmerson. 2000. “Will Indonesia Survive?”dalam Foreign Affairs , May/June hlm. 95

Hidayatul Wakhidah. 2015. Analisis Kelayaka Buku Teks Pelajaran Pendidikan Pancasila dan Kewarganegaraan Kelas VII Kurikulum 2013. Jurnal PPs Unimed dalam download.portalgaruda.org/article.php?...ANALISIS\%20KELAYAKAN $\% 20 B U K U \%$

http://www.bbc.com/indonesia/berita_indonesia/2016/02/160218_indonesia_radik alisme_anak_muda (diakses 19 Desember 2017 pukul 14.26)

http://www.republika.co.id/berita/koran/didaktika/14/12/15/ngm3g840-literasiindonesia-sangat-rendah (diakses 27 Januari 2017 pukul 10.39 WIB)

https://www.komnasham.go.id/index.php/news/2017/01/16/276/pada-2016 intoleransi-meningkat.html (diakses pada 19 Desember 2017 pukul 14.47)

Lemhanas. 1995. Wawasan Nusantara. Jakarta: Penerbit Ismujati.

Loveridge, A.J. 1970. Preparing textbook manuscript: A Guide for author in developing countries. Paris: United Nation Educational and Cultural (UNESCO). 
Muslich, M. 2010. Textbook Writing: Dasar-dasar Pemahaman, Penulisan, dan Pemakaian Buku Teks. Yogyakarta: Ar-Ruzz Media.

M. Anwar Rubei \& Dwi Utami. 2018. Penanaman Sila Ketuhanan yang Maha Esa pada Mata Pelajaran PPKN Kelas XI SMA N 1 Toho Kabupaten Mempawah. Jurnal Pendidikan Kewarganegaraan Vol. 2, Nomor 1, Juni Tahun 2018. (dionlinekan pada http://webcache.googleusercontent.com/search?q=cache:zbcO8sQMnAJ:journal.ikippgriptk.ac.id/index.php/kewarganegaraan/article/downlo $\underline{\mathrm{ad} / 309-318 / 677+\& \mathrm{~cd}=3 \& \mathrm{hl}=\mathrm{id} \& \mathrm{ct}=\mathrm{clnk} \& \mathrm{gl}=\mathrm{id} \& \mathrm{client}=\text { firefox }-\mathrm{b}-\mathrm{ab})}$

Rusman. 2010. Model-Model Pembelajaran:Mengembangkan Profesionalisme Guru, Jakarta: Rajawali Pers.

Sitepu, B.P. 2012. Penulisan Buku Teks Pelajaran. Bandung: PT Remaja Rosdakarya.

Tarigan, HG dan Tarigan, D. 2009. Telaah Buku Teks Bahasa Indonesia. Bandung: Angkasa. 